\title{
Seagrasses of Costa Rica: from the mighty Caribbean to the dynamic meadows of the Eastern Tropical Pacific
}

\author{
Jimena Samper-Villarreal ${ }^{1}$, Brigitta I. van Tussenbroek ${ }^{3}$ \& Jorge Cortés ${ }^{1,2}$ \\ 1. Centro de Investigación en Ciencias del Mar y Limnología (CIMAR), Ciudad de la Investigación, Universidad de \\ Costa Rica, San Pedro, 11501-2060 San José, Costa Rica; jimena.sampervillarreal@ucr.ac.cr, jorge.cortes@ucr.ac.cr \\ 2. Escuela de Biología, Universidad de Costa Rica, San Pedro, 11501-2060 San José, Costa Rica. \\ 3. Unidad Académica Sistemas Arrecifales-Puerto Morelos, Instituto de Ciencias del Mar y Limnología, Universidad \\ Nacional Autónoma de México, México; vantuss@cmarl.unam.mx
}

Received 18-I-2017. Corrected 12-VI-2017. Accepted 03-I-2018.

\begin{abstract}
Seagrass meadows are declining worldwide, mostly attributed to anthropogenic disturbances. Understanding the dynamics of these meadows is urgent in order to establish adequate management and conservation strategies. Here, we analyzed the current knowledge on the seagrass meadows in the Caribbean and Pacific coasts of Costa Rica, Central America. Current knowledge was based on literature searches, herbarium collections, informal interviews, and personal observations. We report a total of five genera and seven species for Costa Rica: Thalassia testudinum, Syringodium filiforme, Halophila decipiens, Halophila baillonis, Halodule wrightii, Halodule beaudettei, and Ruppia maritima. Six species are reported for the Caribbean, and four species for the Pacific. Thalassia testudinum, S. filiforme, and H. decipiens have only been reported for the Caribbean. Halodule beaudettei has only been reported for the Pacific coast. Halophila baillonis, $H$. wrightii and $R$. maritima have been reported for both coasts. Seagrasses were found at a total of 31 locations in Costa Rica, most from the Pacific coast; 16 of which are reported here for the first time. Seagrass meadows from both coasts are vastly different. Along the Caribbean coast, meadows are often dominated by the robust T. testudinum, they are extensive and stable, persisting for decades. In contrast, the meadows along the Pacific coast are more dynamic and are dominated by pioneer and smaller ephemeral species, such as H. baillonis and H. beaudettei. The number of studies on Costa Rican seagrasses is scarce but has been increasing over time, and mostly concern taxonomic reports and basic descriptions of the dynamics of $T$. testudinum meadows from the Caribbean. Research, conservation and management efforts on Costa Rican seagrass meadows would benefit from continued monitoring and research on associated fauna and flora, incorporating ecosystem resilience and services. Rev. Biol. Trop. 66(Suppl. 1): S53-S65. Epub 2018 April 01.
\end{abstract}

Key words: Seagrass meadows, coastal wetlands, Eastern Tropical Pacific, Caribbean, Central America, inventory.

Costa Rica is a small country in Central America with $51000 \mathrm{~km}^{2}$ total land area (Cortés \& Wehrtmann, 2009). The general conditions for seagrass meadows vary greatly between the Caribbean and Pacific coasts, despite both coasts being only $120-285 \mathrm{~km}$ apart. The Pacific coast is very irregular, with a length of $1254 \mathrm{~km}$, has a $\sim 3 \mathrm{~m}$ tidal range, and hosts a wide variety of habitats (Cortés, 2016a). Meanwhile, the Caribbean coast a length of $212 \mathrm{~km}$ with more regular geomorphology, and a much smaller tidal range of approximately $0.5 \mathrm{~m}$ (Cortés, 2016b). Costa Rica hosts $3.5 \%$ of the worlds' marine biodiversity (Wehrtmann, Cortés, \& Echeverría-Sáenz, 2009), which includes the species associated with seagrass meadows on both coasts (Cortés \& Salas, 2009).

Seagrass meadows are important marine habitats that are found along coastlines around the world (Hemminga \& Duarte, 2000). Seagrasses are an ecological group of flowering 
plants that thrive in saline to brackish waters, and there are between 60 and 72 species of seagrass worldwide (Den Hartog \& Kuo, 2006; Short et al., 2011). These plants are the foundation species of diverse coastal ecosystems in shallow waters, with a multitude of associated organisms, providing a plethora of ecosystem services, such as nursery habitat, nutrient recycling, carbon sequestration, sediment deposition, and coastal protection (Nordlund, Koch, Barbier, \& Creed, 2016).

Seagrass meadows are declining worldwide (Waycott et al., 2009), including the Caribbean region (Van Tussenbroek et al., 2014). This decline has been strongly linked to anthropogenic activity, mainly nutrient enrichment, increased sedimentation, and light reduction (Orth, Carruthers, Dennison, Duarte, Fourqurean, Heck, et al., 2006; Waycott et al., 2009). Conservation and management initiatives that aim to preserve the functions and presence of seagrass meadows need to have a strong basis on scientific knowledge, including the location and spatial area of seagrass meadows. Presence of seagrass meadows has been acknowledged for many years in Costa Rica; particularly in the Caribbean (Cortés \& Salas, 2009). Here, we present recent additions to the reported species and locations of seagrasses for Costa Rica. We analyze previous research efforts on Costa Rican seagrass meadows, and identify key areas for further study.

\section{MATERIALS AND METHODS}

Information for this study was gathered by searching google scholar for "Costa Rica + seagrass", "Eastern Tropical Pacific + seagrass", and in Spanish "pastos marinos + Costa Rica", "fanerógamas + Costa Rica". Local library databases were also searched for these terms, and for university thesis, as was the Revista de Biología Tropical online search engine (available at: revistas.ucr.ac.cr). References related to seagrass or seagrass habitat research in Costa Rican coasts were selected for further analyses.
Multiple herbarium collections were searched for Costa Rican seagrass specimens using the different genus and species as keywords. Herbarium specimens from the Herbario Nacional de Costa Rica (CR) and Herbario de la Escuela de Biología, Universidad de Costa Rica (USJ) were photographed and analysed in person. Specimens from the Herbario Nacional de México, Universidad Nacional Autónoma de México (MEXU), were searched digitally online and detailed high resolution photographs of each specimen were assessed (datosabiertos. unam.mx). The information from the specimens at the Missouri Botanical Garden Herbarium (MO) was searched on their online Tropicos database (tropicos.org). Information was also included in this analysis from new herbarium samples collected in recent years that have been recently deposited at CR, USJ and the State Herbarium of South Australia (AD) and have yet to be assigned herbarium identification numbers.

Informal interviews were conducted with local contacts that responded positively when asked if they had ever seen seagrasses on the Pacific coast of Costa Rica. Interviewees included researchers, field technicians and research assistants at the Centro de Investigación en Ciencias del Mar y Limnología (CIMAR) at the Universidad de Costa Rica (UCR), students at the Escuela de Biología, UCR, Non-Government Organization workers, conservation area government workers, divers and local coastal residents. During these interviews, they were asked to identify the species from a plate with pictures of various local seagrass species or to describe details of the spotted plants including the location and date of the sighting. A map was used to identify key locations whenever possible. Maps with identified seagrass locations or names of locations provided during interviews and herbarium samples with only location name were then used to extract approximate coordinates for each meadow using Google Earth (7.1.7.2606). Additional localities have been observed directly by the authors. 


\section{RESULTS}

Seven seagrass species are reported for Costa Rica. Six species are reported for the Caribbean, and four species for the Pacific (see taxonomic considerations for some seagrass species in the discussion). Three species are only present in the Caribbean, and one species is only reported for the Pacific coast of Costa Rica. Three species occur along both coasts (Table 1). Most species are classified as Least Concern in the IUCN Red List; except for Halophila baillonis which is listed as Vulnerable, and Halodule beaudettei is classified as Data Deficient, mainly due to uncertainties concerning its taxonomical status (Table 1).

Seagrasses occur at 31 locations, of which 16 are reported for the first time in this study (Fig. 1, Table 2). These new records consist of herbarium samples collected previously (four locations), personal communications during the informal interviews in this study (seven locations), and recent new sightings by the authors (five locations) (Table 2). Of the locations where seagrasses have been found previously (Table 2), we can confidently say, from recent observations, that seagrasses are present on the Pacific coast at Bahía Jobo, Bahía Culebra, Bahía Potrero, Isla Chora, Punta Leona, Parque Nacional Marino Ballena, and most extensively at Golfo Dulce. In the Caribbean, seagrasses have been observed recently at Isla Uvita, Parque Nacional Cahuita (hereafter PNC), Puerto Viejo, and Refugio Nacional de Vida Silvestre Gandoca-Manzanillo (hereafter RGM). Based on the current information, total seagrass area for Costa Rica is estimated as $1328384 \mathrm{~m}^{2}$ (132.8 ha), most on the Pacific coast.

Seagrasses have been found at ten locations in the Caribbean, with three locations reported in this study for the first time (Table 2). Seagrass presence is limited to sheltered areas near the port city of Limón and in coral reef lagoons further south at PNC and the

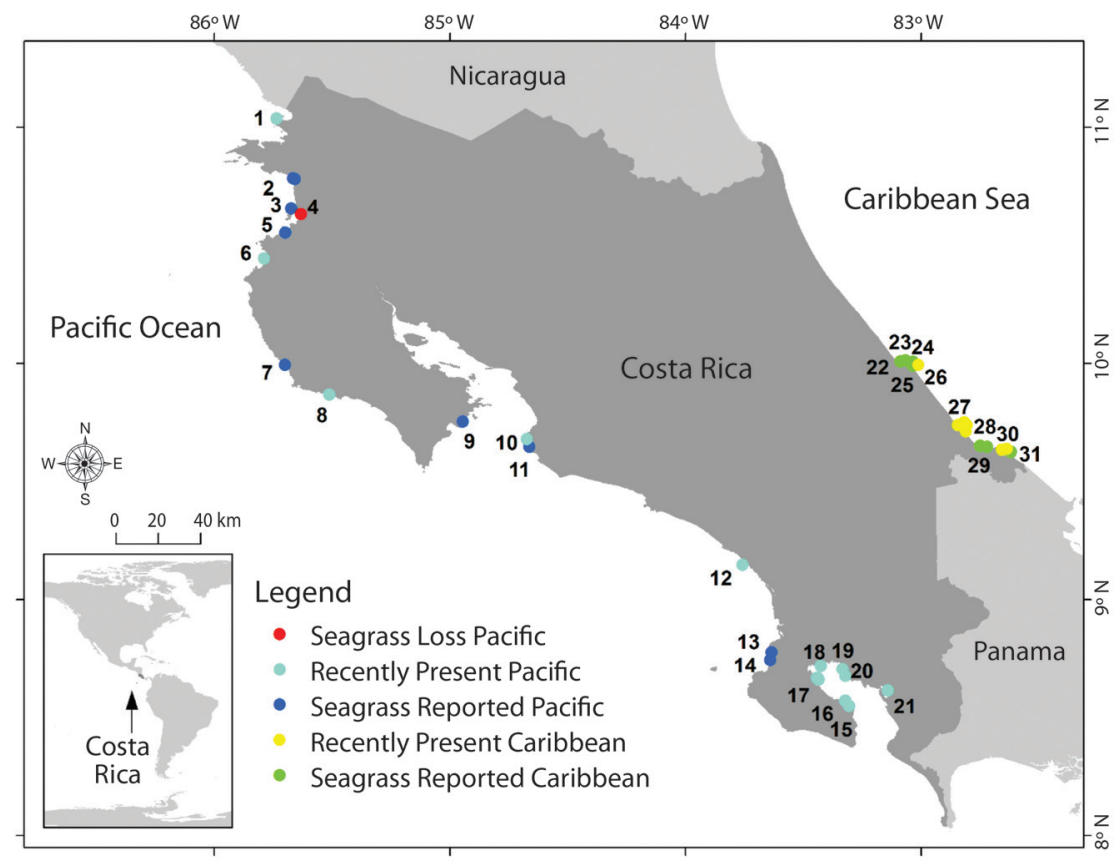

Fig. 1. Seagrass presence on the Pacific and Caribbean coasts of Costa Rica, Central America. Numbers refer to individual seagrass locations (see Table 2). Seagrass categories: "Seagrass Loss" refers to a meadow where seagrasses were lost and have not yet recovered. "Recently Present" refers to meadows which have seen at that location within the current decade. "Reported Seagrass" refers for locations for which there are only older herbarium samples or personal communications. 
TABLE 1

Seagrass species reported for each coast of Costa Rica. IUCN Red List and population trends from Short et al. (2011). Pop = Population Trend Worldwide

\begin{tabular}{|c|c|c|}
\hline Species & Reports in the Caribbean & Reports in the Pacific \\
\hline \multicolumn{3}{|l|}{ Hydrocharitaceae } \\
\hline $\begin{array}{l}\text { Thalassia testudinum } \\
\text { IUCN: Least Concern } \\
\text { Pop: Stable }\end{array}$ & $\begin{array}{l}\text { Dawson, 1962; Den Hartog, 1970; Wellington, 1974; } \\
\text { Risk, Murillo, \& Cortés, 1980; Gómez, 1984; Cortés \& } \\
\text { Guzmán, 1985; Cortés \& Risk, 1985; Phillips \& Meñez, } \\
\text { 1988; Cortés et al., 1992; Davidse, Sousa, \& Chater, } \\
\text { 1994; Cortés \& Jiménez, 2003; Crow, 2003b; Green \& } \\
\text { Short, 2003; Cortés \& Salas, 2009; Cortés et al., 2010; } \\
\text { Krupp, 2006; Krupp, Cortés, \& Wolff, 2009; Nielsen } \\
\text { Muñoz, 2006, 2007; Paynter, Cortés, \& Engels, 2001; } \\
\text { Van Tussenbroek et al., 2010; } \\
\text { Van Tussenbroek et al., 2014; }\end{array}$ & None \\
\hline $\begin{array}{l}\text { Halophila decipiens } \\
\text { IUCN: Least Concern } \\
\text { Pop: Stable }\end{array}$ & $\begin{array}{l}\text { Gómez, 1984; Phillips \& Meñez, 1988; Davidse et al., } \\
\text { 1994; Crow, 2003b; Green \& Short, 2003; Krupp, 2006; } \\
\text { Nielsen Muñoz, 2006, 2007; Nielsen-Muñoz \& Cortés, } \\
\text { 2008; Cortés \& Salas, 2009; } \\
\text { Van Tussenbroek et al., } 2010\end{array}$ & None \\
\hline $\begin{array}{l}\text { Halophila baillonis } \\
\text { IUCN: Vulnerable } \\
\text { Pop: Decreasing }\end{array}$ & $\begin{array}{l}\text { Dawson, 1962; Wellington, 1974; Gómez, 1984; } \\
\text { Phillips \& Meñez, 1988; Crow, 2003b }\end{array}$ & $\begin{array}{l}\text { Gómez, 1984; Phillips \& Meñez, } \\
\text { 1988; Cortés, 2001; Green \& } \\
\text { Short, 2003; Krupp, 2006; Nielsen } \\
\text { Muñoz, 2006, 2007; Cortés \& } \\
\text { Salas, 2009; Van Tussenbroek et } \\
\text { al., 2010 Bessesen \& Saborío-R., } \\
\text { 2012; Sarmento de Carvalho, 2013; } \\
\text { Samper-Villarreal et al., 2014 }\end{array}$ \\
\hline \multicolumn{3}{|l|}{ Cymodoceaceae } \\
\hline $\begin{array}{l}\text { Syringodium filiforme } \\
\text { IUCN: Least Concern } \\
\text { Pop: Stable }\end{array}$ & $\begin{array}{l}\text { Dawson, 1962; Wellington, 1974; Gómez, 1984; Cortés } \\
\text { \& Guzmán, 1985; Phillips \& Meñez, 1988; Cortés et } \\
\text { al., 1992; Davidse et al., 1994; Cortés \& Jiménez, 2003; } \\
\text { Green \& Short, 2003; Hammel, 2003; Cortés \& Salas, } \\
\text { 2009; Krupp, 2006; Nielsen Muñoz, 2006, 2007; Krupp } \\
\text { et al., 2009; Van Tussenbroek et al., } 2010\end{array}$ & None \\
\hline $\begin{array}{l}\text { Halodule wrightii } \\
\text { IUCN: Least Concern } \\
\text { Pop: Increasing }\end{array}$ & $\begin{array}{l}\text { Gómez, 1984; Phillips \& Meñez, 1988; Cortés et al., } \\
\text { 1992; Davidse et al., 1994; Green \& Short, 2003; } \\
\text { Hammel, 2003; Krupp, 2006; Nielsen Muñoz, 2006, } \\
\text { 2007; Cortés \& Salas, 2009; } \\
\text { Van Tussenbroek et al., } 2010\end{array}$ & $\begin{array}{l}\text { Phillips \& Meñez, 1988; Green \& } \\
\text { Short, 2003; Van Tussenbroek et } \\
\text { al., } 2010\end{array}$ \\
\hline $\begin{array}{l}\text { Halodule beaudettei } \\
\text { IUCN: Data Deficient } \\
\text { Pop: Unkown: }\end{array}$ & None & Sarmento de Carvalho, 2013 \\
\hline \multicolumn{3}{|l|}{ Ruppiaceae } \\
\hline $\begin{array}{l}\text { Ruppia maritima } \\
\text { IUCN: Least Concern } \\
\text { Pop: Stable }\end{array}$ & $\begin{array}{l}\text { Dawson, 1962; Gómez, 1984; Davidse et al., 1994; } \\
\text { Cortés \& Salas, 2009; Van Tussenbroek et al., } 2010\end{array}$ & $\begin{array}{l}\text { Gómez, 1984; Phillips \& Menez, } \\
\text { 1988; Davidse et al., 1994; Cortés, } \\
\text { 2001; Crow, 2003a; Nielsen } \\
\text { Muñoz, 2006, 2007; Cortés \& } \\
\text { Salas, 2009; Van Tussenbroek et } \\
\text { al., } 2010\end{array}$ \\
\hline
\end{tabular}


TABLE 2

Seagrass locations reported for the Caribbean and Pacific coasts of Costa Rica, with the date sighted, species present, estimated extension, verification evidence and cited publications. $\mathrm{AD}=$ State Herbarium of South Australia; $\mathrm{CR}=$

Herbario Nacional de Costa Rica; MEXU = Herbario Nacional de México, Universidad Nacional Autónoma de México; JS = Jimena Samper personal code; MO = Missouri Botanical Garden; USJ = Herbario de la Escuela de Biología,

Universidad de Costa Rica. TBA $=$ to be assigned. $\mathrm{nk}=$ Not known

\begin{tabular}{|c|c|c|c|c|c|}
\hline $\begin{array}{l}\text { Location } \\
\text { number } \\
\text { (Fig. 1) }\end{array}$ & Location & $\begin{array}{c}\text { Species } \\
\text { Herbarium collections }\end{array}$ & Extension $\left(\mathrm{m}^{2}\right)$ & $\begin{array}{l}\text { Water } \\
\text { column depth }\end{array}$ & References \\
\hline Pacific & Northern & & & & \\
\hline 1 & Bahía Jobo ${ }^{1}$ & Halophila baillonis & 60000 & $0.5-2 \mathrm{~m}$ & This study \\
\hline 2 & $\begin{array}{l}\text { Playa Naranjo, Parque } \\
\text { Nacional Santa Rosa }\end{array}$ & $\begin{array}{l}\text { Ruppia maritima MO-Grayum \#5131; } \\
\text { CR-119424 }\end{array}$ & nk & nk & Crow, 2003a \\
\hline 3 & Bahía Huevo ${ }^{2}$ & c.f. Ruppia maritima & nk & $1-8 m$ & This study \\
\hline 4 & Bahía Culebra ${ }^{3}$ & $\begin{array}{l}\text { Ruppia maritima* } \\
\text { Halophila baillonis USJ-005824 }\end{array}$ & $<100-5000$ & $<2 \mathrm{~m}$ & Cortés, 2001; Crow, 2003b \\
\hline 5 & Playas del Coco & Ruppia maritima USJ-7228 & nk & nk & This study \\
\hline 6 & Bahía Potrero $^{4}$ & $\begin{array}{l}\text { Halodule beaudettei CR-TBA } \\
\text { Halophila baillonis CR-TBA }\end{array}$ & nk & $6 \mathrm{~m}$ & This study \\
\hline 7 & Estero de Ostional & Ruppia maritima MEXU-546253 & nk & $0 \mathrm{~m}$ & This study \\
\hline 8 & Isla Chora, Sámara ${ }^{5}$ & Halophila baillonis & $\sim 100$ & $3 \mathrm{~m}$ & This study \\
\hline 9 & Bahía Curú $^{2}$ & Halophila baillonis & nk & $1-8 m$ & This study \\
\hline & Central & & & & \\
\hline 10 & $\begin{array}{l}\text { Reserva Biológica de } \\
\text { Punta Leona }\end{array}$ & Unkown & nk & $0-3.5 \mathrm{~m}$ & Myers et al., 2011 \\
\hline 11 & Herradura & Unkown & nk & nk & Cortés, 2001 \\
\hline \multirow[t]{2}{*}{12} & $\begin{array}{l}\text { Parque Nacional } \\
\text { Marino Ballena }\end{array}$ & Ruppia maritima & nk & nk & This study \\
\hline & Southern & & & & \\
\hline 13 & Mouth of Río Siepre & Halophila baillonis MEXU-1249952 & nk & $0.01-0.2 \mathrm{~m}$ & Cortés, 2001 \\
\hline 14 & $\begin{array}{l}\text { Playa Ganado, Bahía } \\
\text { Drake }\end{array}$ & Unkown & nk & nk & $\begin{array}{l}\text { BIOMARCC-SINAC-GIZ, } \\
2012\end{array}$ \\
\hline 15 & $\begin{array}{l}\text { Puerto Jiménez, Golfo } \\
\text { Dulce }^{6}\end{array}$ & $\begin{array}{l}\text { Halodule beaudettei AD-TBA, CR-TBA, } \\
\text { USJ-TBA } \\
\text { Halophila baillonis AD-TBA, CR-TBA, } \\
\text { USJ-TBA }\end{array}$ & $\sim 900$ & $2-3 m$ & This study \\
\hline 16 & $\begin{array}{l}\text { Playa Neques, Golfo } \\
\text { Dulce }^{7}\end{array}$ & c.f. Halophila baillonis & nk & nk & This study \\
\hline 17 & $\begin{array}{l}\text { Playa Colobrí, Golfo } \\
\text { Dulce }^{8,9}\end{array}$ & $\begin{array}{l}\text { Halodule beaudettei USJ-101555, } \\
\text { CR-TBA, AD-TBA, CR-TBA, USJ-TBA } \\
\text { Halodule wrightii MO- } 2525084 \\
\text { Halophila baillonis USJ-101556, } \\
\text { CR-TBA, AD-TBA }\end{array}$ & (> 400) 900000 & $5-6 m$ & $\begin{array}{l}\text { Bessesen \& Saborío-R., } \\
\text { 2012; Sarmento de } \\
\text { Carvalho, 2013; Sarmento et } \\
\text { al., } 2016\end{array}$ \\
\hline 18 & $\begin{array}{l}\text { Rincón, Golfo } \\
\text { Dulce }{ }^{10}\end{array}$ & Halophila baillonis USJ-101557, CR-TBA & 884 & $4-5 m$ & $\begin{array}{l}\text { Samper-Villarreal et al., } \\
2014\end{array}$ \\
\hline 19 & $\begin{array}{l}\text { Piedras Blancas, } \\
\text { Golfo Dulce }^{7}\end{array}$ & c.f. Halophila baillonis & nk & $\mathrm{nk}$ & This study \\
\hline 20 & $\begin{array}{l}\text { Playa Animal, Golfo } \\
\text { Dulce }^{8}\end{array}$ & $\begin{array}{l}\text { Halophila baillonis AD-TBA, CR-TBA, } \\
\text { USJ-TBA }\end{array}$ & $\sim 100$ & $4-5 m$ & This study \\
\hline 21 & Golfito, Golfo Dulce ${ }^{8}$ & $\begin{array}{l}\text { Halophila baillonis AD-TBA, CR-TBA, } \\
\text { USJ-TBA }\end{array}$ & $\sim 1000$ & $<1 \mathrm{~m}$ & This study \\
\hline
\end{tabular}


TABLE 2 (Continued)

\begin{tabular}{|c|c|c|c|c|c|}
\hline $\begin{array}{l}\text { Location } \\
\text { number } \\
\text { (Fig. 1) }\end{array}$ & Location & Species Herbarium collections & Extension $\left(\mathrm{m}^{2}\right)$ & $\begin{array}{l}\text { Water } \\
\text { column depth }\end{array}$ & References \\
\hline Caribbean & Southern & & & & \\
\hline 22 & Moín & $\begin{array}{l}\text { Ruppia maritima } \\
\text { MO-1936778 }\end{array}$ & nk & nk & Dawson, 1962 \\
\hline 23 & Portete & $\begin{array}{l}\text { Thalassia testudinum } \\
\text { Halophila decipiens USJ-038574, USJ- } \\
\text { 038575, USJ-038576 } \\
\text { Halophila baillonis }\end{array}$ & nk & $1 \mathrm{~m}$ & $\begin{array}{c}\text { Dawson, 1962; Cortés \& } \\
\text { Guzmán, 1985; Cortés \& } \\
\text { Jiménez, 2003; Crow, 2003b }\end{array}$ \\
\hline 24 & Piuta $^{2}$ & Thalassia testudinum & nk & $<2 \mathrm{~m}$ & This study \\
\hline 25 & Isla Uvita 2,8 & $\begin{array}{l}\text { Thalassia testudinum } \\
\text { Halophila decipiens USJ-TBA }\end{array}$ & 400 & $8 \mathrm{~m}$ & Cortés \& Guzmán, 1985 \\
\hline 26 & Puerto Limón & Thalassia testudinum CR-66687 & nk & nk & Dawson, 1962 \\
\hline 27 & Cahuita & $\begin{array}{l}\text { Thalassia testudinum MO-A Lot \#1255, } \\
\text { MEXU-366392, CR-062284, CR-274353, } \\
\text { CR-TBA, USJ-017357, USJ-031104, USJ- } \\
\text { 031105, USJ-031106, USJ-037843, USJ- } \\
\text { 024515, CR-198189, USJ-102076, } \\
\text { USJ-92778, USJ-92779 } \\
\text { Syringodium filiforme MO-A Lot \#1258, } \\
\text { MEXU-366595, CR-50.020, CR-138191, } \\
\text { CR-167852, USJ-017312, USJ-037843, USJ- } \\
\text { 104913, USJ-104919, USJ-104920, } \\
\text { USJ-104921, USJ-92780 } \\
\text { Halodule wrightii MO- 2525084, MEXU- } \\
\text { 366577, MEXU-366593, AD-TBA, USJ-TBA } \\
\text { Halophila decipiens MO-684710, MEXU- } \\
\text { 366594, CR-138146, USJ-88569, USJ-85511 }\end{array}$ & 200000 & $0-7 \mathrm{~m}$ & $\begin{array}{l}\text { Dawson, 1962; Wellington, } \\
\text { 1974; Risk et al., 1980; } \\
\text { Cortés \& Guzmán, 1985; } \\
\text { Cortés \& Risk, 1985; } \\
\text { Cortés, 1998; Cortés \& } \\
\text { Jiménez, 2003; Crow, } \\
\text { 2003b; Fonseca et al., 2007; } \\
\text { Wetzer \& Bruce, } 1999\end{array}$ \\
\hline 28 & Puerto Viejo & Thalassia testudinum CR-87408, CR-257304 & nk & nk & This study \\
\hline 29 & Cocles & Thalassia testudinum & Small patches & nk & $\begin{array}{c}\text { Fernández \& Alvarado, } \\
2004\end{array}$ \\
\hline 30 & Manzanillo & $\begin{array}{l}\text { Thalassia testudinum CR-273678 } \\
\text { Syringodium filiforme CR-273679 }\end{array}$ & 160000 & $1-5 \mathrm{~m}$ & $\begin{array}{l}\text { Cortés \& Guzmán, 1985; } \\
\text { Chacón, McLarney, } \\
\text { Ampie, \& Venegas, 1996; } \\
\text { Krupp et al., } 2009\end{array}$ \\
\hline 31 & Punta Mona & Thalassia testudinum CR-93991 & nk & nk & This study \\
\hline
\end{tabular}

Notes: 1. Pers. com. and specimen sampled by M. Heidemeyer. 2. Pers. com. Eleazar Ruiz, 2016. 3. This meadow disappeared in the mid-1990s; there is photographic evidence. 4. Unpublished data JSV \& pers. com. Mauricio Méndez, Javier Espinach, Gustavo Rojas-Ortega sighted 2015 with photographic evidence, 2016. 5. Pers. com. and photographs from Giovanni Bassey, Alvaro Segura y Mauricio Méndez, 2016. 6. Unpublished data JSV \& JCN \& pers. com. Juan Diego Pacheco \& Andrés Beita, 2016. 7. Pers. com. Helena Molina, 2016. 8. Unpublished data JSV \& JC. 9. Juan Esteban Barquero In Prep. 10. Seen again in 2012 by JC. * = only some isolated shoots in the last 15 yrs., pers. obs. JC.

RGM. Seagrasses on the Caribbean coast have been found up to $8 \mathrm{~m}$ deep. The most studied location and with the highest number of species reported for the Caribbean coast is PNC, with four species of seagrass and a total of 37 herbarium samples, dating back to 1975 . The oldest samples of seagrasses found were Thalassia testudinum at Puerto Limón from 1963 and of Ruppia maritima at Moín from 1965 (Table 1). Seagrass area for the Caribbean coast is estimated as $360400 \mathrm{~m}^{2}$ (36.0 ha).

Seagrasses have been found at 21 locations on the Pacific coast, 13 of them reported here for the first time (Table 2). On the Pacific coast 
of Costa Rica, the locations with seagrasses consist mainly of sheltered bays in the northern Pacific coast (eight locations), central Pacific coast (four locations), and the southern Pacific coast (nine locations) (Fig. 1). The most extensive meadow currently present in the Pacific coast is located at Playa Colibrí in Golfo Dulce, with an area up to $900000 \mathrm{~m}^{2}$ and three seagrass species (Table 2). At Bahía Culebra, only isolated shoots of $R$. maritima have been sighted in the last ten years. Seagrasses on the Pacific coast have been found up to $8 \mathrm{~m}$ deep. The oldest herbarium samples refer to $R$. maritima collected in 1967 from Playas del Coco (Table 2). Seagrass area for the Pacific coast is estimated as $967984 \mathrm{~m}^{2}$ (96.8 ha).
A total of 43 studies were found that included or reported seagrasses in Costa Rica, and the number of studies has been steadily increasing over time (Fig. 2). The majority of the studies were done in meadows along the Caribbean coast, and publications on seagrasses from the Pacific coast only appeared after the year 2000 (Fig. 2). Most studies have been taxonomic reports, followed by some ecological studies and monitoring, with recent focus on associated fauna (Fig. 3). The top three most studied species are T. testudinum, followed by Syringodium filiforme and $H$. baillonis, and the least studied species is $H$. beaudettei (Fig. 3).

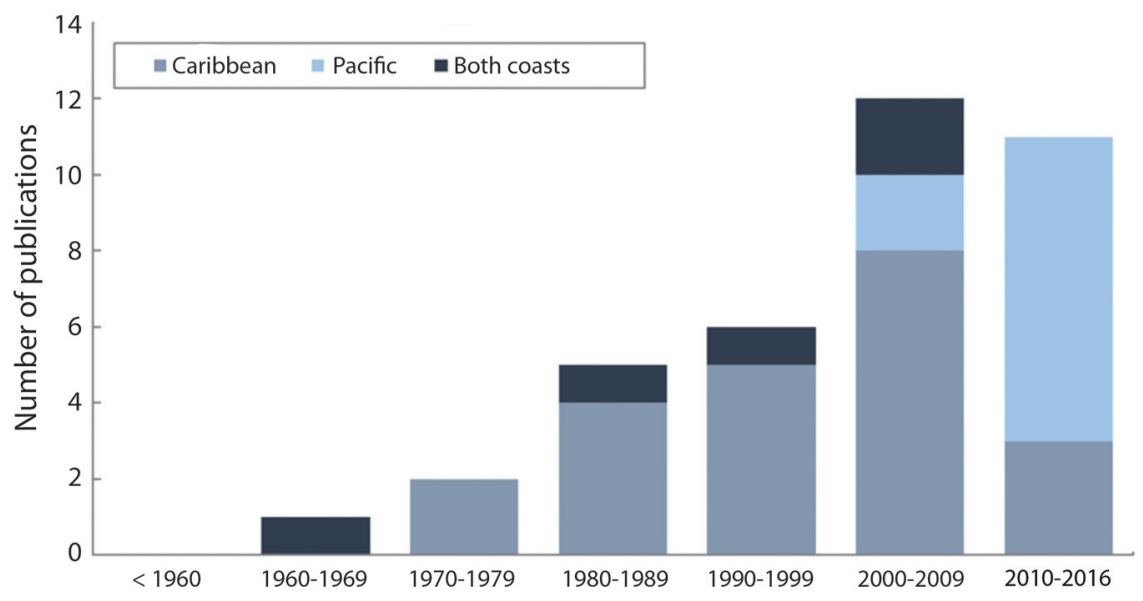

Fig. 2. Number of publications on Costa Rican seagrasses per coast by time period up to December 2016.

\section{A Type of study}

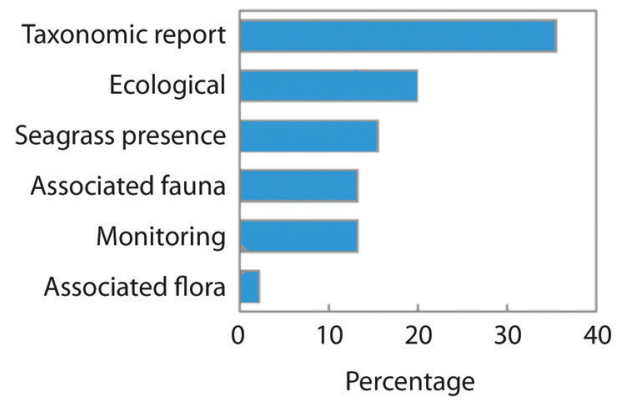

B Seagrass species

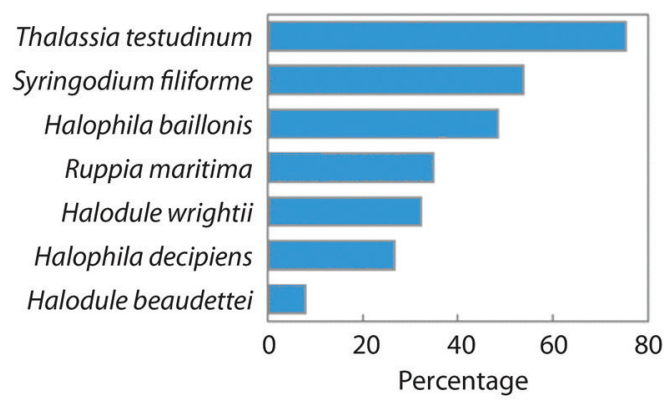

Fig. 3. Percentage of studies on seagrasses of Costa Rica up to December 2016 by (A) type of study, $n=43$; and (B) species, $\mathrm{n}=37$ (percentage indicates the number of the total publications in which that species was mentioned). 


\section{DISCUSSION}

Seven seagrass species have been reported for Costa Rica; however, a number of taxonomic considerations have to be taken into account. Two key aspects are potential misidentifications of seagrass species and the taxonomic standing of some species (Short et al., 2011). The current species name of the clover grass is $H$. baillonis, though there is discrepancy among specialists whether Halophila baillonii should be the correct species used (see Kuo \& Wilson, 2008 for a detailed discussion on the taxonomic standing of the clover grass). In the past, the species $H$. baillonis has been misidentified with Halophila decipiens (Kuo \& Wilson, 2008). The only record of H. baillonis in the Caribbean of Costa Rica was by Dawson (1962), which may have been $H$. decipiens, illustrations were not included. In contrast, $H$. decipiens has been correctly reported for the Caribbean of Costa Rica, with many herbarium samples, and it is currently present at Isla Uvita. Nonetheless, H. baillonis has recently been reported in the Caribbean Sea at Belize (Short, Fernandez, Vernon, \& Gaeckle, 2006), Honduras (Caviedes-Sánchez \& Carrasco, 2016), and in the Atlantic coast of Brazil (Barros, Costa, \& Rocha-Barreira, 2014; Magalhães, Borges, \& Pitanga, 2015); thus, the record by Dawson (1962) may have been correct, and it is also possible that this inconspicuous species may still be found along the Caribbean coasts of Costa Rica.

Another case of misidentification was Halophila engelmannii, reported for the Pacific coast of Costa Rica from a single specimen at the herbarium of the Universidad Nacional Autónoma de México (UNAM) (MEXU-1249952) (Crow, 2003b). High definition photographic material for this specimen was carefully studied by us and we consider the correct species to be $H$. baillonis. The specimen has four short leaves per foliar shoot with oval apices and defined petioles, similar to H. baillonis (Kuo \& Den Hartog, 2001; Van Tussenbroek, Santos, Wong, Van Dijk, \& Waycott, 2010). In addition, $H$. engelmanni has not been reported along the
Pacific coast elsewhere (Phillips \& Menez, 1988; Green \& Short, 2003).

The taxonomy of Halodule needs to be clarified. $H$. beaudettei is considered by some to be a synonym of Halodule wrightii, as it has been argued that leaf-tip morphology is insufficient to define the taxonomic status of the species within this genus (Phillips, 1967). The specimens of $H$. beaudettei, reported here for the first time for the Pacific coast, present an acute median tooth differing from samples of $H$. wrightii from the Caribbean coast (Kuo \& Den Hartog, 2001; Van Tussenbroek et al., 2010). Genetic analyses on $H$. wrightii from the Caribbean and $H$. beaudettei from the Pacific of Costa Rica are currently under way.

Ruppia maritima has been reported for both coasts; however, its verified current presence is extremely limited. In the Caribbean, there is only one herbarium sample from 1965 supporting its presence but there have been no other sightings of this species. On the Pacific coast, there are multiple herbarium samples of this species; yet the only reported meadow disappeared in the mid-1990s; with only some isolated shoots noted in the northern and central Pacific coast in the last 15 years (pers. obs. JCN \& pers. com. Eleazar Ruiz). In Mexico, specimen of this species previously identified as $R$. maritima were considered to belong to a new species Ruppia mexicana (Den Hartog, Van Tussenbroek, Wong, Mercado-Ruaro, \& Márquez-Guzmán, 2016), and therefore careful examination of specimens from Costa Rica should clarify their taxonomic status. A final cautionary note on species in Costa Rica: the newly introduced Halophila stipulacea in the Caribbean has not been found in Costa Rica. Considering its rapid expansion throughout the Caribbean (Willette et al., 2014; Van Tussenbroek et al., 2016) it is most likely just a matter of time before this species will be found on the Caribbean coast of Costa Rica.

Different seagrass species occupy the Pacific and Caribbean coasts of Costa Rica with distinct habits in each coast. In the Eastern Tropical Pacific (ETP), seagrasses belong to the genera Halophila, Halodule and Ruppia 
(Cortés, 2001; Green \& Short, 2003; Short, Carruthers, Dennison, \& Waycott, 2007). These seagrasses are mainly small pioneer or opportunistic species, which can also be ephemeral (Orth et al., 2006; Kendrick et al., 2012). In the Caribbean, seagrass meadows are mostly dominated by the large species T. testudinum, the faster growing S. filiforme, and opportunistic ephemeral H. wrightii (Orth et al., 2006; Van Tussenbroek et al., 2010; Kendrick et al., 2012). In the Pacific, seagrasses develop in deeper or more turbid waters than in the Caribbean, where they are found in shallow coastal or reef lagoons. Even so, both coasts of Costa Rica belong to the Tropical Atlantic seagrass bioregion (Short et al., 2007).

The number of seagrass locations is higher in the Pacific than the Caribbean; yet Caribbean locations are mostly large meadows (Cortés, Soto, \& Jiménez, 1994; Cortés \& Jiménez, 2003), while in the Pacific the largest meadow is found in the southern Pacific coast with many smaller patches. Seagrass presence in the Caribbean is restricted to a sheltered island habitat in the central coast and coral reef lagoons in the southern areas of the Caribbean coast (Cortés \& Guzmán, 1985; Cortés, 2016b). The northern Caribbean coast of Costa Rica is rectilinear, has high wave energy and precipitation leading to higher river effluent than the southern Caribbean, likely hindering seagrass presence there (Cortés, 2016b). Given limited research, current estimates of seagrass coverage in Costa Rica are considered to be an underestimation of actual seagrass area.

On the Pacific coast of Costa Rica, following seagrass loss in the northern Pacific coast in the mid-1990s (Cortés, 2001), there were no other known extant seagrass meadows, until 2009 and 2010 when seagrasses were reported in the southern Pacific coast (Bessesen \& Saborío-R., 2012; Samper-Villarreal, Bourg, Sibaja-Cordero, \& Cortés, 2014; Sarmento de Carvalho, 2013; Sarmento, Chaves, Retamosa, Ruepert, Jiménez, \& Blanco, 2016). In this area, seagrasses have been continuously sighted since, and here we report an additional five new locations. The new sightings may indicate recent colonization by seagrasses in this sheltered fjord-like estuary; however, residents recall the presence of seagrasses at some of these sites for decades.

Seagrass research in Costa Rica has been limited, but has been steadily increasing. Fortythree studies on seagrasses were found, most of which were either taxonomic reports or site descriptions. Presence of seagrasses has also been reported in studies on other organisms such as marine turtles (Sarmento de Carvalho, 2013; Chacón-Chaverri, Martínez-Cascante, Rojas, \& Fonseca, 2015a, 2015b; Sarmento et al., 2016), corals (Fernández \& Alvarado, 2004), and fish (Myers, Wagner, \& Vaughan, 2011). Seagrasses in Costa Rica are subtidal, and are only exposed during the maximum low tides. The absence of large exposed intertidal seagrass beds which can be easily accessed at low tide, common in the Indo-Pacific or temperate regions (Moore \& Short, 2007; Van Tussenbroek et al., 2007), may be an important reason for limited research effort on Pacific seagrasses. The search for seagrass populations in the Pacific is more challenging than in the Caribbean. Pacific seagrass species are smaller, more ephemeral, and occur in deeper or more turbid waters, with tidal ranges $3 \mathrm{~m}$ or higher (Lizano, 2006); while Caribbean meadow species are larger and grow in clearer and calmer waters, with a tidal range of 0.3-0.5 m (Cortés, 1998; Lizano, 2006). In the Caribbean, there has been one continuous monitoring program in place since 1999, the Caribbean Coastal Marine Productivity Program known as CARICOMP (Fonseca, Nielsen, \& Cortés, 2007; Cortés et al., 2010); which accounts for all the monitoring publications focusing on plant biomass, productivity and turnover rates. Studies on grazing and non-charismatic organisms associated with seagrass meadows are very limited, with only one study focused on macroalgal epiphytes in the Caribbean (Samper-Villarreal, Bernecker, \& Wehrtmann, 2008), and one study mentioning limited grazing and associated macrofauna in the southern Pacific (Samper-Villarreal et al., 2014). Seagrasses in the southern Pacific coast are known 
as a resting, breeding and foraging area for green sea turtles and they are important locations along migratory routes (Bessesen \& Saborío-R., 2012; Sarmento de Carvalho, 2013; Chacón-Chaverri et al., 2015a, 2015b). Given the Vulnerable status of $H$. baillonis according to the IUCN red list (Short et al., 2011) and the importance of these meadows for sea turtles, conservation and management initiatives of these meadows is warranted.

Seagrasses in Costa Rica are subjected to multiple disturbances, and further research on seagrass meadows in Costa Rica is urgently needed to establish management and conversation initiatives. Loss of seagrasses in the northern Pacific coast followed a severe storm resulting in light deprivation from increased and prolonged water turbidity, and uprooting of the plants (Cortés, 2001). These seagrass meadows have shown no signs of recovery to date. In 1991, the Limón Earthquake caused coastal uplifting of the Caribbean coast (Cortés, Soto, Jiménez, \& Astorga, 1992; Cortés et al., 1994; Cortés \& Jiménez, 2003), which resulted in the subaerial exposure and subsequent die-off of more than $40000 \mathrm{~m}^{2}$ of seagrass (Cortés et al., 1992; Cortés et al., 1994). Another impact was whitening and shedding of T. testudinum leaves in 2005 following heavy storms at Manzanillo; but leaf regrowth shortly resumed afterwards and no permanent damage to the meadows was reported (Krupp, 2006; Krupp et al., 2009). The long-term monitoring program in Caribbean meadows has revealed a decline over time, most likely due to increased turbidity (Van Tussenbroek et al., 2014). In November 2016 Level 4 hurricane Otto passed through the country, with high wave and wind energy and increased precipitation. Other threats are local, such as increased turbidity from land alteration, increased nutrient runoff, and anchoring on seagrass meadows (Cortés \& Risk, 1985; Orth et al., 2006; Cortés et al., 2010). Further research, monitoring, management and conservation strategies are needed for Costa Rican seagrasses, with a stronger focus needed on research looking at associated fauna and flora, and incorporating ecosystem resilience and services.

\section{ACKNOWLEDGEMENTS}

This research was funded by the Vicerrectoría de Investigación at the University of Costa Rica (project 808-B6-170). International academic exchange linked to this work was supported by the Oficina de Asuntos Internacionales y Cooperación Externa (OAICE), Universidad de Costa Rica, and Centro de Estudios Mexicanos, Universidad de Costa Rica-Universidad Nacional Autónoma de México. We would like to thank all those that contributed to seagrass research and herbarium maintenance in previous years. Our thanks to the many individuals who shared their knowledge on seagrass sightings with us.

\section{RESUMEN}

Pastos marinos de Costa Rica: del majestuoso Caribe a las praderas dinámicas del Pacífico Este Tropical. Las praderas de pasto marino están deteriorándose a nivel mundial ligado a disturbios antropogénicos. Esta degradación resalta la necesidad de entender las dinámicas ecológicas de estos sistemas costeros para definir estrategias de manejo y conservación adecuadas. Aquí, nosotros analizamos el conocimiento actual sobre praderas de pastos marinos en las costas Caribe y Pacífico de Costa Rica, América Central. El conocimiento actual se basó en revisiones de literatura, colecciones de herbarios, entrevistas y observaciones personales. Reportamos un total de cinco géneros y siete especies para Costa Rica: Thalassia testudinum, Syringodium filiforme, Halophila decipiens, Halophila baillonis, Halodule wrightii, Halodule beaudettei y Ruppia maritima. Se reportan seis especies para el Caribe y cuatro especies para el Pacífico. Thalassia testudinum, $S$. filiforme y $H$. decipiens solamente han sido reportadas para el Caribe. Halodule beaudettei está solamente en la costa Pacífica. Halophila baillonis, H. wrightii y $R$. maritima son reportadas para ambas costas. Se encontraron pastos marinos en un total de 31 sitios en Costa Rica, la mayoría en el Pacífico; 16 de los cuales se reportan aquí por primera vez. Las praderas de pastos marinos de ambas costas son sumamente diferentes. En el Caribe, hay praderas extensas dominadas por una especie grande, T. testudinum, las cuales han estado presentes por décadas. En contraste, las praderas en la costa Pacífica son más dinámicas ya que están dominadas por especies pioneras y efímeras, principalmente $H$. baillonis y $H$. beaudettei. El número de estudios sobre pastos marinos en Costa Rica es limitado, pero ha estado 
creciendo de manera constante, enfocándose principalmente en reportes taxonómicos y ecología de $T$. testudinum en la costa Caribe. Esfuerzos de investigación, conservación y de manejo se verían benefíciados por una continuación del monitoreo e investigación detallada en pastos marinos, pero también sobre la flora y fauna asociada, incorporando análisis de resiliencia del ecosistema y sus servicios.

Palabras Clave: Praderas de pasto marino, fanerógamas, humedales costeros, Pacífico Este Tropical, Caribe, América Central, Centroamérica, inventario.

\section{REFERENCES}

Barros, K., Costa, F., \& Rocha-Barreira, C. (2014). A Halophila baillonis Ascherson bed on the semiarid coast of Brazil. Feddes Repertorium, 125(3-4), 93-97.

Bessesen, B. L., \& Saborío-R., G. (2012). Tropical fiord habitat as a year-round resting, breeding, and feeding ground for East Pacific green sea turtles (Chelonia mydas) off Costa Rica. Herpetological Review, 45(4), 539-541.

BIOMARCC-SINAC-GIZ. (2012). Estudios cientificos de hábitat marino costero y situación socio-económico del pacifico sur de Costa Rica. Biodiversidad Marina y Costera de Costa Rica. San José, Costa Rica.

Caviedes-Sánchez, V., \& Carrasco, J. C. (2016). Primer registro de pradera de Halophila baillonii en Honduras. Revista Mexicana de Biodiversidad, 87(1), 248-251.

Chacón, D., McLarney, W., Ampie, C., \& Venegas, B. (1996). Reproduction and conservation of the leatherback turtle Derrnochelys coriacea (Testudines: Dermochelyidae) in Gandoca, Costa Rica. Revista de Biología Tropical, 44(2), 853-860.

Chacón-Chaverri, D., Martínez-Cascante, D. A., Rojas, D., \& Fonseca, L. G. (2015a). Golfo Dulce, Costa Rica, un área importante de alimentación para la tortuga carey del Pacífico Oriental (Eretmochelys imbricata). Revista de Biología Tropical, 63(Suppl. 1), 351-362.

Chacón-Chaverri, D., Martínez-Cascante, D. A., Rojas, D., \& Fonseca, L. G. (2015b). Captura por unidad de esfuerzo y estructura poblacional de la tortuga verde de Pacífico (Chelonia mydas) en el Golfo Dulce, Costa Rica. Revista de Biología Tropical, 63(Suppl. 1), 363-373.

Cortés, J. (1998). Cahuita and Laguna Gandoca, Costa Rica. In B. Kjerfve (Ed.). CARICOMP. Caribbean Coral Reef, Seagrass and Mangrove Sites (pp. 107113). Paris, France: United Nations Educational, Scientific and Cultural Organization (UNESCO).

Cortés, J. (2001). Requiem for eastern Pacific seagrass bed. Revista de Biología Tropical, 49(Suppl. 2), 273-278.
Cortés, J. (2016a). The Pacific coastal and marine ecosystems. In M. Kappelle (Ed.). Costa Rican Ecosystems (pp. 97-138). Chicago and London: University of Chicago Press.

Cortés, J. (2016b). The Caribbean coastal and marine ecosystems. In M. Kappelle (Ed.). Costa Rican Ecosystems (pp. 591-617). Chicago and London: University of Chicago Press.

Cortés, J. \& Guzmán, H. M. (1985). Arrecifes coralinos de la costa Atlántica de Costa Rica. Brenesia, 23: 275-292.

Cortés, J., \& Risk, M. J. (1985). A reef under siltation stress: Cahuita, Costa Rica. Bulletin of Marine Science, 36(2), 339-356.

Cortés, J., \& Jiménez, C. (2003). Past, present and future of the coral reefs of the Caribbean coast of Costa Rica. In J. Cortés (Ed.). Latin American Coral Reefs (pp. 223-239). Amsterdam: Elsevier Science B.V.

Cortés, J., \& Salas, E. (2009). Seagrasses. In I. S. Wehrtmann \& J. Cortés (Eds.). Marine Biodiversity of Costa Rica, Central America (pp. Text: 119-122, Species List: Compact Disc pp. 171-172). Berlin: Springer + Business Media B.V.

Cortés, J., \& Wehrtmann, I. S. (2009). Diversity of marine habitats of the Caribbean and Pacific of Costa Rica. In I. S. Wehrtmann \& J. Cortés (Eds.). Marine Biodiversity of Costa Rica, Central America (pp. 1-45). Berlin: Springer + Business Media B.V.

Cortés, J., Soto, R., \& Jiménez, C. (1994). Efectos ecológicos del terremoto de Limón. Revista Geológica de América Central, vol. esp. Terremoto de Limón, 187-192.

Cortés, J., Soto, R., Jiménez, C., \& Astorga, A. (1992). Earthquake associated mortality of intertidal and coral reef organisms (Caribbean of Costa Rica). Proc. 7th Int. Coral Reef Symp., Guam, 1, 235-240.

Cortés, J., Fonseca, A. C., Nivia-Ruiz, J., Nielsen-Muñoz, V., Samper-Villarreal, J., Salas, E., Martínez, S., \& Zamora-Trejos, P. (2010). Monitoring coral reefs, seagrasses and mangroves in Costa Rica (CARICOMP). Revista de Biología Tropical, 58(Suppl. 3), 1-22.

Crow, G. E. (2003a). Potamogetonaceae. In B. E. Hammel, M. Grayum, C. Herrera, \& N. Zamora (Eds.). Manual de Plantas de Costa Rica. Volúmen III. Monocotiledóneas (Orchidaceae-Zingiberaceae) (pp. 829-832). St Louis, Missouri, U.S.A.: Missouri Botanical Garden Press.

Crow, G. E. (2003b). Hydrocharitaceae. In B. E. Hammel, M. Grayum, C. Herrera, \& N. Zamora (Eds.). Manual de Plantas de Costa Rica. Volúmen II. Gimnospermas y Monocotiledóneas (Agavaceae-Musaceae) 
(pp. 593-299). St Louis, Missouri, U.S.A.: Missouri Botanical Garden Press.

Davidse, G., Sousa, S., \& Chater, A. O. (Eds.). (1994). Flora Mesoamericana. Volumen 6. Alismataceae a Cyperaceae. México: Instituto de Biología, Universidad Nacional Autónoma de México (UNAM), Missouri Botanical Garden \& The Natural History Museum (London).

Dawson, E. Y. (1962). Additions to the marine flora of Costa Rica and Nicaragua. Pacific Naturalist, 3(13), 375-395.

Den Hartog, C. (1970). The Sea-Grasses of the World. Amsterdam, London: North-Holland Publishing Company.

Den Hartog, C., \& Kuo, J. (2006). Taxonomy and biogeography of seagrasses. In A. Larkum, R. Orth, \& C. M. Duarte (Eds.). Seagrasses, Biology, Ecology and Conservation (pp. 1-23). The Netherlands: Springer.

Den Hartog, C., Van Tussenbroek, B., Wong, J., MercadoRuaro, P., \& Márquez-Guzmán, J. (2016). A new Ruppia from Mexico: Ruppia mexicana n.sp. Aquatic Botany, 131, 38-44.

Fernández, C., \& Alvarado, J. J. (2004). El arrecife coralino de Punta Cocles, costa Caribe de Costa Rica. Revista de Biología Tropical, 52(Suppl. 2), 121-129.

Fonseca, A. C., Nielsen, V., \& Cortés, J. (2007). Monitoreo de pastos marinos en Perezoso, Cahuita, Costa Rica (sitio CARICOMP). Revista de Biología Tropical, 55(1), 55-66

Gómez, L. D. (1984). Las plantas acuaticas y anfibias de Costa Rica y Centramerica. 1. Liliopsida. San Jose, Costa Rica: Editorial Universidad Estatal a Distancia.

Green, E. P., \& Short, F. T. (2003). World Atlas of Seagrasses. Berkeley, USA: University of California Press.

Hammel, B. E. (2003). Cymodoceaceae. In B. Hammerl, M. Grayum, C. Herrera, \& N. Zamora (Eds.). Manual de Plantas de Costa Rica. Volúmen II. Gimnospermas y Monocotiledóneas (Agavaceae-Musaceae) (pp. 456-457). St Louis, Missouri, U.S.A.: Missouri Botanical Garden Press.

Hemminga, M. A., \& Duarte, C. M. (2000). Seagrass Ecology. Cambridge, United Kingdom: Cambridge University Press.

Kendrick, G. A., Waycott, M., Carruthers, T. J., Cambridge, M. L., Hovey, R., Krauss, S. L., ... Verduin, J. J. (2012). The central role of dispersal in the maintenance and persistence of seagrass populations. BioScience, 62(1), 56-65.

Krupp, L. S. (2006). Distribution, ecology and state of the seagrass beds in the Gandoca-Manzanillo National
Wildlife Refuge, Caribbean Costa Rica (Master's thesis). Bremen, Germany: University of Bremen.

Krupp, L. S., Cortés, J., \& Wolff, M. (2009). Growth dynamics and state of the seagrass Thalassia testudinum in the Gandoca-Manzanillo National Wildlife Refuge, Caribbean Costa Rica. Revista de Biología Tropical, 57(Suppl. 1): 187-201.

Kuo, J., \& Den Hartog, C. (2001). Seagrass taxonomy and identification key. In F. Short \& R. Coles (Eds.). Global Seagrass Research Methods (pp. 31-58). The Netherlands: Elsevier Science B.V.

Kuo, J., \& Wilson, P. G. (2008). Nomenclature of the seagrass Halophila baillonis Ascherson. Aquatic Botany, 88(2), 178-180.

Lizano, O. G. (2006). Algunas características de las mareas en la costa Pacífica y Caribe de Centroamérica. Revista de Ciencia y Tecnología, 24(1), 51-64.

Magalhães, K. M., Borges, J. C., \& Pitanga, M. E. (2015). Halophila baillonis Ascherson: first population dynamics data for the Southern Hemisphere. Anais da Academia Brasileira de Ciências, 87(2), 861-865.

Moore, K. A., \& Short, F. T. (2007). Zostera: biology, ecology, and management. In A. Larkum, R. J. Orth, \& C. M. Duarte (Eds.). Seagrasses: Biology, Ecology and Conservation (pp. 361-386). The Netherlands: Springer.

Myers, M. C., Wagner, J., \& Vaughan, C. (2011). Longterm comparison of the fish community in a Costa Rican rocky shore marine reserve. Revista de Biologia Tropical, 59(1), 233-246.

Nielsen-Muñoz, V. 2006. Capítulo IV, Pastos marinos. In V. Nielsen-Muñoz, \& M. A. Quesada-Alpízar (Eds.). Ambientes Marino Costeros de Costa Rica (pp. 41-49). San José, Costa Rica: Comisión Interdisciplinaria Marino Costera de la Zona Económica Exclusiva de Costa Rica, Informe Técnico. CIMAR, CI, TNC.

Nielsen Muñoz, V. (2007). Abundancia, biomasa y floración de Thalassia testudinum (Hydrocharitaceae) en el Parque Nacional Cahuita, Caribe de Costa Rica (Licenciatura's thesis). San José, Costa Rica: Universidad de Costa Rica.

Nielsen-Muñoz, V. \& Cortés, J. (2008). Abundancia, biomasa y floración de Thalassia testudinum (Hydrocharitaceae) en el Caribe de Costa Rica. Revista de Biología Tropical, 56(Suppl. 4): 175-189.

Nordlund, L. M., Koch, E. W., Barbier, E. B., \& Creed, J. C. (2016). Seagrass ecosystem services and their variability across genera and geographical regions. PLoS one, 11(10), e0163091.

Orth, R. J., Carruthers, T. J. B., Dennison, W. C., Duarte, C. M., Fourqurean, J. W., Heck Jr, K. L., ... Olyarnik, 
S. (2006). A global crisis for seagrass ecosystems. Bioscience, 56(12), 987-996.

Paynter, C.K., Cortés, J., \& Engels, M. (2001). Biomass, productivity and density of the seagrass Thalassia testudinum at three sites in Cahuita National Park, Costa Rica. Revista de Biología Tropical, 49(Suppl. 2): $265-272$.

Phillips, R. (1967). On species of the seagrass, Halodule, in Florida. Bulletin of Marine Science, 17(3), 672-676.

Phillips, R., \& Meñez, E. (1988). Seagrasses. Smithsonian Contribution to the Marine Sciences, Number 34. Washington, DC: Smithsonian Institute Press.

Risk, M., Murillo, M., \& Cortés, J. (1980). Observaciones biológicas preliminares sobre el arrecife coralino en el Parque Nacional Cahuita, Costa Rica. Revista de Biología Tropical, 28, 361-382.

Samper-Villarreal, J., Bernecker, A., \& Wehrtmann, I. S. (2008). Inventory of macroalgal epiphytes on the seagrass Thalassia testudinum (Hydrocharitaceae) in Parque Nacional Cahuita, Caribbean coast of Costa Rica. Revista de Biología Tropical, 56(4), 163-174.

Samper-Villarreal, J., Bourg, A., Sibaja-Cordero, J. A., \& Cortés, J. (2014). Presence of a Halophila baillonii Asch.(Hydrocharitaceae) seagrass meadow and associated macrofauna on the Pacific Coast of Costa Rica. Pacific Science, 68(3), 435-444.

Sarmento de Carvalho, M. M. (2013). Análisis descriptivo de las condiciones ambientales y estado de salud de la tortuga negra (Chelonia mydas agassizii) en un sitio de Forrajeo en el Golfo Dulce, Costa Rica (Master's thesis). Heredia, Costa Rica: Universidad Nacional.

Sarmento, M., Chaves, A., Retamosa, M., Ruepert, C., Jiménez, R., \& Blanco, K. (2016). Análisis descriptivo de las condiciones de conservación de un sitio de forrajeo de la tortuga verde del Pacífico (Chelonia mydas agassizii, Testudines: Chelonioidea) en el Golfo Dulce, Costa Rica; se toma como base el estado de salud de la tortuga y el hallazgo de plaguicidas en el ambiente. Revista Ciencias Veterinarias, 33(2), 81-96.

Short, F. T., Fernandez, E., Vernon, A., \& Gaeckle, J. (2006). Occurrence of Halophila baillonii meadows in Belize, Central America. Aquatic Botany, 85(3), 249-251.

Short, F. T., Carruthers, T., Dennison, W., \& Waycott, M. (2007). Global seagrass distribution and diversity: A bioregional model. Journal of Experimental Marine Biology and Ecology, 350(1), 3-20.
Short, F. T., Polidoro, B., Livingstone, S. R., Carpenter, K. E., Bandeira, S., Bujang, J. S., ... Zieman, J. C. (2011). Extinction risk assessment of the world's seagrass species. Biological Conservation, 144(7), 1961-1971.

Van Tussenbroek, B., Vonk, J. A., Stapel, J., Erftemeijer, P. L., Middelburg, J. J., \& Zieman, J. C. (2007). The biology of Thalassia: paradigms and recent advances in research. In A. Larkum, R. J. Orth, \& C. M. Duarte (Eds.). Seagrasses: Biology, Ecology and Conservation (pp. 409-439). The Netherlands: Springer.

Van Tussenbroek, B., Santos, M. G. B., Wong, J. G. R., Van Dijk, J. K., \& Waycott, M. (2010). A Guide to the Tropical Seagrasses of the Western Atlantic. México D.F.: Universidad Nacional Autónoma de México.

Van Tussenbroek, B., Cortés, J., Collin, R., Fonseca, A. C., Gayle, P. M., Guzmán, H. M., Jácome, G. E., ... Weil, E. (2014). Caribbean-wide, long-term study of seagrass beds reveals local variations, shifts in community structure and occasional collapse. PloS one, $9(3)$, e90600.

Van Tussenbroek, B., Van Katwijk, M., Bouma, T., van der Heide, T., Govers, L., \& Leuven, R. (2016). Nonnative seagrass Halophila stipulacea forms dense mats under eutrophic conditions in the Caribbean. Journal of Sea Research, 115, 1-5.

Waycott, M., Duarte, C. M., Carruthers, T. J. B., Orth, R. J., Dennison, W. C., Olyarnik, S., ... Hughes, A. R. (2009). Accelerating loss of seagrasses across the globe threatens coastal ecosystems. Proceedings of the National Academy of Sciences, 106(30), 12377-12381.

Wehrtmann, I. S., Cortés, J., \& Echeverría-Sáenz, S. (2009). Marine biodiversity of Costa Rica: perspectives and conclusions. In I. S. Wehrtmann \& J. Cortés (Eds.). Marine Biodiversity of Costa Rica, Central America (pp. 521-533). Berlin: Springer + Business Media B.V.

Wellington, G. (1974). The benthic flora of Punta Cahuita: an annotated list of species with new additions to the Costa Rican Atlantic flora. Brenesia, 3, 19-30.

Wetzer, R., \& Bruce, N. L. (1999). A new genus and species of sphaeromatid isopod (Crustacea) from Atlantic Costa Rica. Proceedings of the Biological Society of Washington, 112, 368-380.

Willette, D. A., Chalifour, J., Debrot, A. D., Engel, M. S., Miller, J., Oxenford, H. A., ... Védie, F. (2014). Continued expansion of the trans-Atlantic invasive marine angiosperm Halophila stipulacea in the Eastern Caribbean. Aquatic Botany, 112, 98-102. 